\title{
What do hospices do? A survey of hospices in the United Kingdom and Republic of Ireland
}

\author{
Ian S Johnson, Corinne Rogers, Bronwen Biswas, Sam Ahmedzai
}

Abstract

Objective-To obtain baseline information about hospice clinical activity.

Design-Survey of hospices by postal questionnaire and telephone interview.

Setting-98 Hospices in the United Kingdom and Republic of Ireland of $\mathbf{1 1 1}$ that had a named matron or senior nurse, including 17 funded by NHS and 81 independent units.

Participants-Hospice matrons or nursing sisters in charge, to whom the questionnaire was addressed.

Results - Median age of hospices was 7 years, and those built during the past seven years had a median of 12 inpatient beds. All NHS hospices had some input from a medical consultant whereas $12(15 \%)$ of independent units did not. 72 Hospices had home care teams and 12 of 20 of these randomly contacted by telephone provided 24 hour cover. The median number of whole time equivalent nurses was four, but $6(30 \%)$ of teams did not include a doctor. Wide variations were found in discharge rates (range $1-76 \%)$ and throughput $(1 \cdot 7-31 \cdot 8$ patients/bed/year). In units with a full time consultant or medical director throughput was greater and more patients had palliative surgery and became organ donors than in units without $(45 / 48 v 38 / 50$ and 45/48 $v 25 / 50$, respectively). With the exception of pulmonary function tests and insertion of nasogastric tubes and indwelling epidural catheters, tests and procedures were used by over $90 \%$ of hospices, although sometimes the patient had to be transferred elsewhere.

Conclusions-Respondents from units with a full time consultant or medical director were more likely to choose a "technical" description of their unit, such as "a pain relief centre" than those without, who favoured non-technical descriptions. These differences are likely to increase with the appointment of more fully trained consultants in palliative medicine.

\section{Introduction}

During the past decade the number of hospices in the United Kingdom has more than doubled. Many are partly funded by the NHS yet retain their independent status and often do not submit routine data to the district health authority for comparison with other similar units. Consequently there is little information that might be used to describe the work of a "typical" hospice, if indeed such a thing exists. Our survey was undertaken to provide baseline data about hospice activity that might be used not only by those interested in planning services for terminally ill patients and by managers who are involved in funding such services but also by hospice staff themselves to provide a yardstick against which to compare their own pattern of care.

\section{Method}

A questionnaire was sent to all hospices providing inpatient care for adult cancer patients in the United Kingdom and Republic of Ireland that had been identified from the 1988 Directory of Hospice Services ${ }^{1}$ as having a named matron or senior nurse, to whom the questionnaire was addressed. This approach was used in an attempt to obtain the most consistent and accurate picture of actual hospice activity. We thought that there was a higher degree of uniformity among hospice matrons than among hospice doctors, many of whom work part time and may not have ready access to the information being sought. Such criteria excluded newly established units that had not yet made such appointments and presumably were not yet fully operational. Replies were anonymous and because of the high initial response rate no reminders were sent. Additional information about home care was obtained by telephone interviews in a random sample of 20 hospices drawn from the hospice directory.

Data were analysed with the Mann-Whitney U test and $\chi^{2}$ test with Yates's correction. Two tail probability estimates are given in the tables.

\section{Results}

Of 111 questionnaires sent, 98 were returned, a response rate of $89 \%$. The survey thus included $85 \%$ of the hospice inpatient units listed in the 1988 Directory of Hospice Services (four did not meet inclusion criteria and there were 13 non-responders). No attempt was made to include isolated home care teams, of which there are currently about 170 in the United Kingdom.

Seventeen hospices were funded entirely by the NHS at the time of reply, 12 of them having received initial funding from Cancer Relief Macmillan Fund. The remaining 81 hospices were independent units, funded primarily by charitable donations but with a greater or lesser contribution to their revenue costs made by the NHS. This contribution varied between 0 and $100 \%$ (unpublished data) with a mean of $27 \%$.

The median age of the hospices in this survey was 7 years. Table I shows the increase in the number of hospices in recent years, which has been accompanied by a clear trend towards building smaller units $\left(r_{s}=\right.$ $0 \cdot 6401, p<0 \cdot 001$ ). The median number of beds in each hospice has fallen from 25 in units built more than seven years ago to 12 in the more recently established units.

Thirteen $(76 \%)$ of the NHS hospices had at least one full time consultant, the remaining four $(24 \%)$ NHS hospices each being served by at least one part time consultant. Among the independent hospices, 35 $(43 \%)$ had full time and $34(42 \%)$, part time consultant grade medical staff or medical directors. The remaining $12(15 \%)$ had no such doctor, and senior medical cover was provided either by part time general practitioner clinical assistants or by local general practitioner
Correspondence to: Dr Johnson. 
principals, on whose medical lists the hospice patients were included as temporary residents.

Seventy one respondents $(72 \%)$ indicated that they provided a home care service. Of the 20 hospices surveyed by telephone, $14(70 \%)$ had at least one doctor on the team, $12(60 \%)$ provided 24 hour cover, and $14(70 \%)$ provided weekend cover. The median number of whole time equivalent home care nurses was four (range 1-6) with a median caseload of 21.5 patients per nurse. Nine teams (45\%) used Macmillan nurses (that is, nurses whose posts were established with financial help from Cancer Relief Macmillan Fund), all of whom were based in the hospice. Units with a home care team did not have significantly different discharge rates from those without.

The median discharge rate (patients discharged home after an admission) was 30\% (range 1-76\%). Throughput also varied greatly among units with a median of 15 deaths and discharges per bed per year (range $1 \cdot 7-31 \cdot 8$ ). Throughput was significantly increased in units where there was a full time consultant or medical director compared with units without this level of medical support (table II). A similar pattern was seen in the number of units that referred patients for palliative surgery and for organ donation (table III). No difference was found for discharge rates or referral for palliative radiotherapy. The types of investigation and clinical procedures undertaken in hospices varied according to whether or not a full time consultant or medical director was available. Wherever there was a significant trend, activity was highest where such a doctor was available (table IV).

The questionnaire included a list of short descriptions that could be applied to a hospice, and the respondents were asked to identify the one that applied most aptly to them. Two of the statements were "technical" ("a pain relief centre"; "a specialist

TABLE II - Relation of hospice activity to presence of consultant grade staff

\begin{tabular}{lccl}
\hline & $\begin{array}{c}\text { Full time } \\
\text { consultant }\end{array}$ & $\begin{array}{c}\text { No full time } \\
\text { consultant }^{\star}\end{array}$ & $\begin{array}{c}\text { p Value of } \\
\text { difference } \dagger\end{array}$ \\
\hline $\begin{array}{l}\text { Median discharge } \\
\text { rate }(\%)\end{array}$ & $33 \cdot 3$ & $28 \cdot 3$ & $>0.05$ \\
Median throughput & $16 \cdot 4$ & $11 \cdot 5$ & $<0.0002$ \\
\hline
\end{tabular}

^Includes units with part time consultants.

†Mann-Whitney U test.

TABLE III - Number of hospices referring patients to other hospital services by presence of consultant grade staff

\begin{tabular}{lccc}
\hline & $\begin{array}{c}\text { No }(\%) \text { with full time } \\
\text { consultant }(\mathbf{n}=48)\end{array}$ & $\begin{array}{c}\text { No }(\%) \text { without full time } \\
\text { consultant }{ }^{\star}(\mathbf{n}=50)\end{array}$ & p Value of differencet \\
\hline Radiotherapy & $48(100)$ & $47(94)$ & $>0.05$ \\
Surgery & $45(94)$ & $38(76)$ & $<0.05$ \\
Organ donation $\neq$ & $45(94)$ & $25(50)$ & $<0.001$ \\
\hline
\end{tabular}

^Includes units with part time consultants.

tr. test, $\mathrm{df}=1$

¥Includes cornea donation.

TABLE IV-Relation of clinical activity in hospices to presence of full time consultant medical staff

$\%$ (No) with full time $\%$ (No) without full time

consultant $(n=48) \quad$ consultant $^{\star}(n=50)$

p Value of differencet

\section{Transfusions}

Draining ascites

Draining pleural effusion

Treating hypercalcaemia

Epidural injections (initiating use)

Epidural catheters (continuing use)

Using syringe driver

Using nebuliser

Inserting urinary catheter

Inserting nasogastric tube

Blood tests

Pulmonary function tests

$X$ ray examinationst

Bone scanst

* $\gamma$ : test, $\mathrm{df}=1$

Procedures
$75(36)$
$98(47)$
$90(43)$
$90(43)$
$71(34)$
$58(28)$
$100(48)$
$100(48)$
$100(48)$
$73(35)$
Investigations
$98(47)$
$33(16)$
$98(47)$
$96(46)$

$52(26)$

$82(41)$

$58(29)$

$82(41)$

$34(17)$

$44(22)$

$100(50)$
$94(47)$

$94(47)$
$100(50)$

$72(36)$

$100(50)$

$18(9)$

$98(49)$

$90(45)$

$>0 \cdot 05$ medical/nursing unit") and four were "non-technical" ("a peaceful haven"; "just like a family"; "Home from home"; "A place for compassion and dignity"). Thirty two respondents identified their unit with a technical description, 49 with a non-technical one, and 17 gave no response or multiple responses. When replies were analysed with respect to the presence or absence of a full time consultant or medical director there was a significant trend for units with such medical support to see themselves as technical and those without to see themselves as non-technical ( $\chi^{2}$ with Yates's correction $=11 \cdot 63, \mathrm{df}=1, \mathrm{p}<0 \cdot 001)$.

\section{Discussion}

Although most hospices provide a home care service, it is surprising that about a third of these do not include a doctor on the team and that many do not provide 24 hour and weekend cover. In this respect we would agree with the proposals that an ideal home care service should have a medical advisor able to undertake domiciliary visits and that night sitters be available when needed. ${ }^{3}$ It is equally surprising that the presence of a home care team was not reflected in discharge rates. The effectiveness of such teams in helping patients to avoid admission to hospice or hospital or to reduce length of stay cannot, however, be assessed from these results.

Despite the recommendations of the 1980 report on terminal care services ${ }^{+}$the number of hospices has continued to grow over the past decade. Estimates of the need for inpatient services for the terminally ill range from 20 to 117 beds per million population. ${ }^{5.7} \mathrm{By}$ the end of 1988 there were over 2300 such beds in the United Kingdom and Republic of Ireland (with almost 100 planned for 1989)' - that is, approximately 38 beds per million. It is not at all clear, however, to what extent the regional imbalances noted in previous reports ${ }^{89}$ have now been redressed and in how many areas there is still a need for more hospices to provide the bare minimum of inpatient service.

It seems clear, however, that among those hospices that are currently caring for patients there is much variation in the ways in which care is delivered. Indeed, it is difficult to imagine that units that vary so widely in their throughput $(1 \cdot 7-31.8$ deaths and discharges per bed per year) and in their discharge rates $(1-76 \%)$ have much in common other than their title of hospice. Away from these extremes, however, the median values for these measures should help to dispel the continuing misconception among the public and some health professionals that the sole function of a hospice is to provide "tender loving care" during the last few days of life. Not only are many patients discharged from (rather than die in) a hospice but our findings suggest that their management is likely to include a range of investigations and procedures that are usually associated with acute hospital care.

Perhaps more surprising than the large proportion of hospices that gave blood transfusions, tapped pleural effusions and ascites, and so on, was the very small number that stated that they considered a particular test or treatment never to be appropriate for their patients. Only using epidural catheters (16\% never), inserting nasogastric tubes $(19 \%)$, and performing pulmonary function tests $(33 \%)$ were considered inappropriate by more than $10 \%$ of respondents. We made no attempt, however, to assess how often and in what manner these tests and procedures were performed, and this needs further investigation.

Our findings suggest that more use is made of invasive procedures and that patients are more likely to be referred for palliative surgery and organ donation in hospices where there is a full time consultant or medical director. The divergence in clinical practice 
was also carried over into the hospices' perception of themselves as essentially "technical" if there was a fulltime consultant or "non-technical" if there was not. Following the Royal College of Physicians' recognition of palliative medicine as a new specialty it is likely that these differences will increase with the advent of a generation of "accredited hospice consultants," who will displace the "enthusiastic amateurs" of the past.

We thank all the respondents to the survey and the nurses at the Leicestershire Hospice for their interest and willing participation, Dr Carol Jagger for statistical help, and Miss K Jeffery for preparing the typescript.
1 St Christopher's Hospice Information Service. 1988 Directory of hospice serictes. Svidenham: St Christopher's Hospice, 1988

2 Hill F, Oliver C. Hospice - the cost of in-patient care. Health Trends 1984:16: 9-11

3 Ward AWM. Home care services for the terminally ill. A report for the Nufficld Foundation. Sheffield: Medical Care Research Unit, University of Sheffield Medical School, 1985.

4 Department of Health and Social Security. Report of the working group on terminal care. London: HMSO, 1980

5 Wilkes E. Terminal cancer at home. Lancet. 1965; ; 799-801.

6 Porter KRO. Four recurring themes. Br.Med f 1973;i:40-1.

7 Alderson MR. Care of the dying. Br.Med F 1973;i:170.

8 Lunt B. Terminal cancer care: specialist services av'uilable in Great Britain in 1980. Southampton: Wessex Regional Cancer Organisation, University of Southampton, 1980 .

9 Smith T. Hospices: the future. Br Med F 1985;291:1670.

(Accepted 21 1)ecember 1989)

\section{New Drugs}

\section{New antiviral and antifungal drugs}

Peter G Davey

Considerable advances have been made in treating viral and fungal diseases since the last series of reports was published in 1983; several new drugs have been introduced and new clinical data on older drugs collected. This review aims at giving general clinicians a guide to changes since 1983 in licenced antiviral or antifungal treatment in the United Kingdom and briefly discusses when specialist advice about experimental treatment should be sought. Vaccines are not considered.

Department of Clinical

Pharmacology, Ninewells

Hospital and Medical

School, Dundee DD1 9SY

P G Davey, MD, senior

lecturer in clinical

pharmacology and infectious

diseases

BrMed f 1990;300:793-8

Currently licensed indications for treatment with acyclovir

\section{Antiviral drugs}

Nine drugs are currently licensed for antiviral treatment in the United Kingdom: seven (acyclovir, amantadine, ganciclovir, idoxuridine, tribavirin, vidarabine, and zidovudine) have direct effects on viral replication, and two (inosine pranobex and interferon alfa) act by modulating the immune system. Except for amantadine, the drugs with direct antiviral activity are nucleoside analogues that interfere with viral DNA or RNA replication and may also affect mammalian nucleic acids. The newest drugs (acyclovir, ganciclovir, and zidovudine) achieve greater antiviral specificity because they are inactive until phosphorylated by enzymes that are preferentially synthesised by virally infected cells.

\section{ACYCLOVIR}

Acyclovir (Zovirax, Wellcome) was available in 1983 but there have been substantial recent changes in the licenced indications, notably approval of high dose oral treatment for shingles. The manufacturers have recently produced a detailed monograph with 211 references, which is an excellent source of information.

\section{Indications, doses, and costs}

These are summarised in the table. The clinical indications for the use of this drug continue to expand as experience grows. In particular, long term (3-4 year)

\begin{tabular}{|c|c|c|c|c|}
\hline Formulation & Licenced indications & Recommended dose & $\begin{array}{l}\text { Cost a day } \\
\text { (BNF prices) }\end{array}$ & Comments \\
\hline Cream & $\begin{array}{l}\text { Primary herpes labialis or } \\
\text { genitalis in } \\
\text { immunocompetent patients }\end{array}$ & $\begin{array}{l}\text { Application five times a } \\
\text { day }\end{array}$ & $£ 1.07-£ 3.23$ & $\begin{array}{l}\text { Much less effective for secondary than for primary infections. Treatment is unlikely } \\
\text { to be effective unless new lesions are still forming }\end{array}$ \\
\hline \multirow[t]{2}{*}{ Ointment } & Herpes simplex keratitis & $\begin{array}{l}\text { Application five times a } \\
\text { day }\end{array}$ & About $£ 1.05$ & $\begin{array}{l}\text { Little difference between acyclovir, idoxuridine, and vidarabine for superficial } \\
\text { disease but acyclovir is probably superior for deep infections. Experimental } \\
\text { combinations of acyclovir with interferon alfa have been reported to be superior to } \\
\text { acyclovir alone } \\
\text { Unlicensed use: often used for ophthalmic shingles, but probably adds little to } \\
\text { systemic treatment }\end{array}$ \\
\hline & $\begin{array}{l}\text { Primary or secondary herpes } \\
\text { labialis or genitalis in } \\
\text { immunocompetent patients }\end{array}$ & 200 mg five times a day & $£ 5.00$ & $\begin{array}{l}\text { Cnlicensed use: treatment in pregnancy Much less effective for secondary than for } \\
\text { primary infections. Does not eliminate vaginal carriage so delivery by caesarean } \\
\text { section is recommended to avoid neonatal herpes infection }\end{array}$ \\
\hline \multirow[t]{4}{*}{ Tablets and suspension } & $\begin{array}{l}\text { Recurrent herpes in } \\
\text { immunocompetent or } \\
\text { immunocompromised } \\
\text { patients }\end{array}$ & $\begin{array}{l}200 \text { mg four times a day } \\
\text { prophylaxis) }\end{array}$ & $£ 4.00$ & $\begin{array}{l}\text { A controlled clinical trial showed that } 200 \mathrm{mg} \text { four times a day was more effective than } \\
400 \mathrm{mg} \text { twice or } 800 \mathrm{mg} \text { once a day to prevent recurrent genital herpes in } \\
\text { immunocompetent hosts. Reduction of daily dose to } 200 \mathrm{mg} \text { three to two times a } \\
\text { day should be considered after } 2-3 \text { months of maintenance }\end{array}$ \\
\hline & Shingles & $800 \mathrm{mg}$ five times a day & $£ 25.00$ & $\begin{array}{l}\text { Treatment must be started within } 72 \text { hours of onset to be effective and should be } \\
\text { reserved for patients with severe pain. Efficacy in presenting postherpetic } \\
\text { neuralgia is controversial. }\end{array}$ \\
\hline & $\begin{array}{l}\text { (a) In immuncompetent } \\
\text { patients }\end{array}$ & & & \\
\hline & Herpes simplex encephalitis & $10 \mathrm{mg} / \mathrm{kg}$ three times a day & $£ 50.00$ & $\begin{array}{l}\text { Treatment must be started as soon as diagnosis is made. Delayed treatment is much } \\
\text { less effective. Neonatal treatment is less effective for type } 2 \text { than type } 1 \text { herpes } \\
\text { simplex virus. }\end{array}$ \\
\hline \multirow{4}{*}{ Injection } & Severe herpes genitalis & $5 \mathrm{mg} / \mathrm{kg}$ three times a day & $£ 25.00$ & Unlikely to be more effective than oral treatment. \\
\hline & Severe shingles & $5 \mathrm{mg} / \mathrm{kg}$ three times a day & $£ 25.00$ & $\begin{array}{l}\text { Unlikely to be more effective than oral treatment. } \\
\text { Unlicensed use: Anecdotal evidence for efficacy against chickenpox pneumonia, } \\
\text { which is a life threatening condition even in immunocompetent patients }\end{array}$ \\
\hline & $\begin{array}{l}\text { (b) In immunocompromised } \\
\text { patients }\end{array}$ & & & \\
\hline & Herpes simplex or shingles & $\begin{array}{l}10 \mathrm{mg} / \mathrm{kg} \text { three times a } \\
\text { day (treatment or } \\
\text { prophylaxis) }\end{array}$ & $£ 50.00$ & \\
\hline
\end{tabular}

$\mathrm{BNF}=$ British National Formulary. 